\title{
Las decisiones didácticas de los docentes de Ciencias Naturales en grados agrupados en el contexto de ruralidad
} Estado de avance de una Investigación Educativa

\author{
Galfrascoli, Adrián; ${ }^{1}{\text { Lederhos, } \text { Maricel }^{2} \text {; Veglia, Silvia. }}^{3}$
}

\section{Resumen}

La enseñanza de las Ciencias Naturales en el aula plurigrado en contextos rurales comprende una complejidad escasamente estudiada en el ámbito de la Didáctica. La heterogeneidad manifiesta en el alumnado torna inapropiadas las propuestas diseñadas para ámbitos de enseñanza urbanos, con aulas que albergan un gran número de alumnos, del mismo grado escolar.

Por lo tanto, describir cómo los docentes en actividad en ámbitos rurales desarrollan las prácticas de enseñanza de las Ciencias, puntualizando cómo resuelven los problemas que les plantea esta particularidad, será un avance en la constitución de los fundamentos que la Didáctica intenta especificar para sentar bases normativas y avanzar en propuestas para la mejora.

En relación a lo mencionado, el presente texto se propone socializar el estado de avance de la investigación: "La práctica de enseñanza de las Ciencias Naturales en Plurigrado" a realizarse en el contexto santafesino por un equipo interinstitucional conformado por investigadores de la Escuela Normal Superior No 30 de Esperanza y el Instituto Superior de Profesorado $N^{\circ} 4$ de Reconquista, ambas localidades de la provincia de Santa Fe.

Palabras clave: decisiones didácticas, educación rural, plurigrado, didáctica de las Ciencias Naturales.

Presentado: 20-8-13 | Aceptado: 24-10-13

${ }^{1}$ Instituto Superior de Profesorado № 4, Reconquista, Santa Fe, Argentina. Calle 302, No 108, Avellaneda, Santa Fe. adriang@trcenet.com.ar

${ }^{2}$ Escuela Normal Superior $N^{\circ} 30$ "Domingo Faustino Sarmiento" Crespo 3420. Esperanza, Santa Fe, Argentina. maricellederhos@gmail.com

${ }^{3}$ Escuela Normal Superior № 30 “Domingo Faustino Sarmiento" Maipú 2216, Esperanza, Santa Fe, Argentina. vazzos@arnet.com.ar 


\section{Summary}

\section{The educational decisions of teachers of natural sciences in grades grouped in the context of rural life}

Natural Science teaching in the multi-grade classroom in rural contexts comprises a complexity scarcely studied in the Didactics field. The heterogeneity showed in pupils makes the proposals designed for urban teaching fields inappropriate, with classrooms that house a vast number of students, with the same school degree.

Therefore, describing the way in which teachers in rural fields develop the Science teaching practices, focusing on how they solve the problems that this particularity presents to them, will be a progress/ an improvement in the creation of the fundaments which Didactics attempts to specify to set normative basis and make progress in proposals for improving.

In relation to the previously mentioned aspects, this text is intended to socialize the progress/ advance condition of the investigation: "Natural Science teaching practice in multi-grade", to be developed in the Santa Fe region/context by an inter-institutional team formed by researchers from Escuela Normal Superior $N^{\circ} 30$ in Esperanza, and from Instituto Superior de Profesorado $\mathrm{N}^{\circ} 4$ in Reconquista, both cities located in Santa Fe province.

Keywords: educational decisions, rural education, plurigrado, didactics of natural sciences. 